\title{
Turnaround Learner Discipline Practices through Epistemic Social Justice in Schools
}

\author{
Rudzani Israel Lumadi \\ https://orcid.org/0000-0001-9466-2854 \\ University of South Africa \\ lumadri@unisa.ac.za
}

\section{Abstract}

Researchers claim that learner discipline has continued to be a problem in schools since corporal punishment was outlawed in public schools in South Africa. It is evident that teachers have a vital role to play in the improvement of learner discipline in schools. An interpretivist qualitative approach was adopted to investigate learner discipline practices as perceived by teachers in South African public schools. A sample of 10 (3 principals, 3 teachers, 3 parents and 1 learner) participants was used for the study. Social justice theory was used as a lens to consider the process of humanising learner discipline practices in terms of human rights. The article investigates how learner discipline practices can be turned around through epistemic social justice to influence the quality of teaching and learning in schools. The findings revealed that in South Africa there are no effective learner discipline practices. There is a need for education authorities to introduce compulsory training and development programmes for aspiring teachers to be equipped with new strategies to deal with learner discipline through a social justice approach. Social justice theory was used as a tool to address learner discipline practices in selected schools. It was recommended that there be more parent involvement in decision-making to consider a policy of transforming learner discipline practices to deal with the inequality and injustice in schools.

Keywords: turnaround; corporal punishment; school governing bodies; classroom discipline; cultural diversity; learner discipline practices; South African Schools Act; social justice

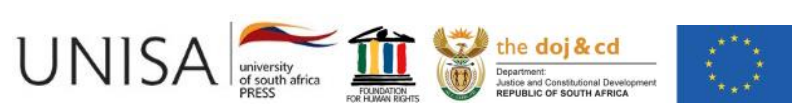




\section{Introduction}

According to research, there is a consensus that from a historical perspective the legal demand for the adoption and implementation of social justice policies still presents challenges associated with learner discipline in South African schools (Mpanza 2015). There are numerous published studies worldwide that describe the role of discipline as a possible tool for promoting quality education in schools (Gregory, Skiba, and Mediratta 2017). There is, however, limited research in the South African context with special reference to secondary schools on the implications of the social justice theory in terms of maintaining learner discipline and school functionality. In 1994, South Africa adopted the most important building block for establishing democracy based on the protection of the fundamental rights as enshrined in the Bill of Rights in line with global school disciplinary demands. As Woolman and Fleisch (2009) note, the values of human dignity, equal treatment and freedom are listed in section 7(1) of the Constitution. While this seems to be a noble idea, South Africa has continuously faced many disciplinary challenges in its schools such as bullying, school-based violence, gender-based violence, segregation, sexual abuse, physical aggression and emotional violence (Smit 2009). Of all the identified forms of indiscipline, researchers agree that bullying is the most serious issue being experienced on a daily basis in South African schools (Thornberg 2015). Although the South African Schools Act, No. 84 of 1996, in compliance with the Constitution, was introduced to replace the inequalities of the apartheid policies, including disciplinary policies and practices, learner discipline is still an unbearable problem, especially in terms of bullying (Amanchukwu 2011). There is also evidence of a negative relationship between undisciplined practices by learners and the quality of teaching and learner performance (Gregory, Skiba, and Mediratta 2017). The effective and efficient functioning of schools, the goal of which is to achieve quality education, is a nightmare under such circumstances, according to Amanchukwu (2011). With the aim of overcoming such challenges, this study investigates how learner discipline practices can be turned around through epistemic social justice to promote quality teaching and learning in secondary schools in the Vhembe district of Limpopo. The findings not only aim at contributing to the enhancement of social justice theoretical content, but also at the implementation and adoption of its principles and practices in the South African education system. The article sketches the background to the study, followed by the problem statement, aims and objectives and the literature review, which consists of the theoretical framework, conceptual framework and further discussion.

\section{Background to the Study}

The South African government invests in education with the expectation of producing a skilled labour force. Russell and Cranston (2012) claim that despite the investment, teachers, as highlighted in the introductory remarks, seem to be concerned about the prevalence of learner disciplinary problems in school environments, which result in a low standard of learner academic performance. Similarly, teachers play a significant role in improving learners' academic achievement and the social and moral 
development of learners in schools. Teachers could transform learner discipline practices through social justice theory in schools with the hope of fostering better educational performance (Russell and Cranston 2012). Central to this study is the assumption by the researcher that learner discipline is critical in the process of transforming and restoring social order.

Before identifying literature gaps in the context of this study, it is important to understand that epistemic social justice refers to the principle of applying fairness in terms of epistemological knowledge and understanding (Fricker 2007). In its opposite context (social injustice), the theory is aligned to the concept of epistemic injustice with reference to such terms as authority and power, suppression and knowledge and understanding (Fricker 2007). The epistemic justice theory, from a social justice perspective, was aimed at abolishing social inequalities (Petrie et al. 2006). It is also important to take note of the emphasis on the terms "knowledge" and "understanding". Social justice in schools is part of the underlying principles of social pedagogy, in accordance with the principles of equity (Rawls 1999). In order to live in a socially just world, all citizens need to be involved in protecting and promoting the values, principles and ideals of social justice (Nieuwenhuis, Aston-Jones, and Cohen 2005). In the context of this study, social justice is used as a possible tool to ensure that fairness is applied by eradicating power, oppression and any form of social inequality when it comes to learner disciplinary issues, and the focus is on knowledge and understanding as key principles.

Before digging deeper into more debates, the controversial issues to be tackled first include an understanding of whether social justice and democracy are the same. Woolmann and Fleisch (2009) claim that South Africa is not aware of the difference between social justice and democracy, according to the majority of educators, school management team (SMT) and school governing body (SGB) members interviewed for their study. What they found in most schools when it comes to disciplinary measures was autocracy, while democratic practices that lead to social justice were hardly practised.

\section{Knowledge and Understanding of Social Justice and Democracy}

According to Thompson $(2015,7)$, social justice fosters the perfect conditions for the rights, security, opportunities, and social benefits of every member of an organisation to be realised. In other words, democracy is a judicial requirement and an instrument for implementing social justice and vice versa (Xaba and Ngubane 2010). Research indicates that from a historical perspective, corporal punishment during the apartheid era was part of an authoritarian approach of managing the school environment, and discipline was based on the view that teachers should control learners (Porteus, Vally, and Ruth 2001). Injustice and unfair measures used to maintain discipline were reactive, humiliating, and punitive rather than corrective and nurturing (DoE 2012). Porteus, Vally, and Ruth (2001) contend that learner discipline in schools was often erroneously equated with punishment. Ugboko and Adediwura (2012) assert that learner discipline 
provides the order and structure needed to maintain the standard of expected learner behaviour in schools. The implication is that more knowledge and a better understanding of the principles of social justice and democracy can encourage a better understanding of appropriate principles and practices of social justice when it comes to disciplinary measures in schools. It is then necessary, in the context of this study, to suggest strategies to ensure that all education stakeholders have full knowledge and understanding of these principles for the successful implementation of disciplinary measures, including educators, the SMT, learners, parents, the SGB and the school community.

Misconceptions associated with democracy, social justice, and human rights have been found among many learners (Elam, Rose, and Gallup 1993). Some of them perceive democracy as protecting their right not to undergo disciplinary processes and relevant punishments for violating school laws (Elam, Rose, and Gallup 1993). For learners, democracy provides leeway for violence and bullying. Research has shown that this is one of the reasons why some of them react so violently to educators (Elam, Rose, and Gallup 1993). On the other hand, this misconception is a threat to teachers' security as disciplinary problems are at alarming levels in South Africa (Elam, Rose, and Gallup 1993).

Bearing this in mind, a strategy must be devised to address this issue through understanding learner discipline as an important part of the learners' behaviourwithout it, the school will not be effective in achieving quality teaching and learning. Learner discipline allows the school to instil an environment conducive to learning for the school community.

\section{Knowledge and Understanding of Bullying as a Form of Indiscipline versus Principles and Practices of Social Justice}

There are also identified literature gaps between knowledge and understanding of causes of bullying and the appropriate strategies to provide a remedy. While some researchers associate causes of school violence and bullying with gender (Burger et al. 2015), others associate it with social norms (Goldsmid and Howie 2014). From a different perspective, some link bullying to wider contextual and structural factors (Goldsmid and Howie 2014). For instance, a study by Higson-Smith and Brookes (2001) reflects on gender inequality and the prevalence of violence against women in society. Similarly, social norms that support the authority of teachers over children may legitimise the use of violence to maintain discipline and control (Goldsmid and Howie 2014). This cannot be separated from the context of this study, since all the causes are linked to social justice policies, principles and practices in every aspect of life, including school discipline. "Proponents of social justice believe in the eradication of imbalances regarding gender, religion, socio-economic status, race or tribe" (Thompson 2015, 7). 


\section{Bullying versus the Teacher-Learner Relationship}

According to Charles (2002), the last literature gap relates to understanding not only teacher-learner relations, but also the roles of the school management team, the SGB and the community at large. He explains there is a perception that only the classroom teacher is responsible for instilling discipline among the learners. This is probably because the teacher spends more time with the learners. However, the policy stipulations indicate that it is the responsibility of all educational staff members, the school management team, the parents, the SGB and the community at large, to instil good behaviour among learners. This is the reason why strategies must be put in place to ensure that all stakeholders have complete knowledge of the concept of full involvement in moulding the behaviour of school learners. In the same vein, teachers do not only teach knowledge and skills, they also help learners to define whom they are (Charles 2002).

\section{Problem Statement}

According to Elam, Rose, and Gallup (1993), learner discipline is viewed as a major problem for schools. It comes as no surprise that most disciplinary problems are caused by students (Elam, Rose, and Gallup 1993). There are identified knowledge gaps that seem to have escalated the prevalence of indiscipline, such as a lack of knowledge and understanding of social justice and democracy. Most consulted strategies have failed to combat these misconceptions of social justice, democracy and what the protection of human rights entails. This challenge is tied to gaps identified in the literature between knowledge and an understanding of bullying as a form of discipline and principles and practices of social justice (Elam, Rose, and Gallup 1993). Challenges associated with social injustice such as gender inequalities, racism, socio-economic status bias, religious inequalities, tribalism and power abuse can be discussed separately, but should not be separated when attempting to solve learner behavioural challenges.

Spaull (2013) confirms that globally the poor academic performance of learners could be attributed to a lack of learner discipline in schools. Teachers, students, school governing bodies (SGBs), and community members are not equally represented in the design of turnaround disciplinary procedures.

My study focuses on exploring the emerging trends and challenges that teachers encounter with learner discipline strategies to restore learner discipline. Turnaround learner discipline practices based on social justice theory reflect the contention that socially responsible actions and responses are learned in a culture where individuals are respected and well-integrated into a social network (Morrison 2001). The question remains how learner discipline practices can be turned around through epistemic social justice theory to foster quality teaching and learning in schools. The researcher proposes remedies that might bring social justice in classroom discipline in schools in line with the provisions of the South African Schools Act (SASA) (RSA 1996a) with regard to 
the effective and efficient management and discipline of learners. There is something wrong in schools when wealthy, low ability children overtake poor, high ability children. Teachers are the modern engines of social justice and need to continue with their mission to embed social justice in schools. The best means of translating intent into positive practice is to have good teachers for disadvantaged learners.

Given this background, this article argues that teachers do not seem to have the relevant knowledge to deal with the learner discipline they experience to enhance the school environment and learning conditions. It is likely to contribute to the body of knowledge in education and to inform practices and policy implementation. It is very important to reward learners for good behaviour and positive contributions to the school community. Effective learner discipline practices are used to turn around the school environment through consistency and teamwork. Moreover, there should be ongoing evaluation of school discipline practices and strategies for reducing classroom disruptions in view of academic achievement (Epstein 2011).

However, the quality of leadership makes a significant contribution to schools and learner outcomes, and it is recognised that schools require effective teachers if they are to provide learner discipline. Teachers can affect classroom management by adopting a proactive approach and becoming instructional leaders. However, sometimes the role of all stakeholders, including educators, SMT, SGB, the parents, the community and society at large, in moulding learners' behaviour seems to be neglected, resulting in another gap that needs to be addressed.

The identified challenges are common in secondary schools in the Vhembe district in Limpopo, which is experiencing a disciplinary crisis. For this reason, an investigation is required to come up with better strategies to turn around learner discipline practices in their own right within a specific terrain of public debate. This will help the principals, teachers, and parents to execute learner discipline practices effectively. Consequently, this article will outline turnaround learner discipline practices required to support the implementation of discipline that can be envisioned and included in the training of classroom teachers. Such an investigation requires that education policymakers examine turnaround learner discipline practices in their own right within a specific terrain of public debate.

\section{The Aim of the Study}

The main aim of the article is to investigate how learner discipline practices can be turned around through epistemic social justice to influence the quality of teaching and learning in the Vhembe secondary schools in Limpopo.

\section{Research Question}

This article is guided by the following research question: 
- How can learner discipline practices be turned around through epistemic social justice to improve the quality of teaching and learning in schools?

\section{Literature Review and Conceptual Framework}

The key aspects, bullying and positive teacher-learner relations, inform the discussion.

\section{Discipline Practice}

There is a consensus among many researchers that disciplinary practices relate to the actions taken by a teacher or the school organisation towards a student or group of students when they violate school rules (Dalporto 2013). While some researchers perceive the term "discipline" as referring to forms of punishment inflicted on a learner for breaking the rules, others put more emphasis on the aim of discipline as setting limits to avoid unbecoming behaviours among school learners that may harm other learners or that are against school policies, norms and ethics (DoE 2012). However, discipline is generally perceived as the provision of necessary guidance and support for children's behaviour for them to be responsible and obedient not only in following school policies, but also to maintain principles of humanity at home and within society at large, among other people and the world around them (Dalporto 2013).

\section{Epistemic Social Justice}

In addition to what has already been highlighted, Fricker (2007) points out that in terms of power and the ethics of understanding and knowing, there are two kinds of epistemic injustice, namely testimonial injustice and hermeneutical injustice (Anderson 2005; Medina 2012). In the context of discipline in schools, Fricker asserts that testimonial injustice takes place when a person's knowledge and understanding are ignored or if they are ignored because the person is a member of a particular social group. This type of injustice includes aspects such as gender, "race", socio-economic, religious, and epistemic oppression. Hermeneutical injustice, on the other hand, occurs when someone's experiences in terms of poverty, family background, abuse or violations of other ethical values are not understood.

However, the key aspects of bullying, as a form of indiscipline, and teacher-learner relations inform the discussion in this study in the sections to follow.

\section{Bullying}

As highlighted before, teachers and learners describe bullying as a serious problem in schools.

Bullying is a social phenomenon that is established and perpetuated over time as the result of the complex interplay between individual and contextual factors (Thornberg 2015). To deal with ill-disciplined children, to reduce barriers to learning, and to 
increase participation of learners require insight into where these barriers may come from and why and when they arise. In support of this, Caravita, Blasio, and Salmivalli (2009) are of the view that it is very important for a teacher to be aware of the socioeconomic and family background of children to be able to understand non-academic factors that influence their learning. Many social factors that affect learning cannot be altered, but understanding these factors will enable teachers to see learners' "failures" in context and create learning environments that reduce, instead of increase, the effects of these factors (Cassidy 2009). Some teachers consider this a personal and professional challenge. The timing of teaching-learning interactions is part of learner discipline management. Learner indiscipline can be overcome by managing the classroom environment better and by improving the timing of classroom activities. Teachers tend to point out learners' deficiencies rather than praising them for their efforts and improvements. For many children, this is very discouraging and may result in them feeling inferior and like a failure. Effective teachers have learned and experienced that learner indiscipline is relatively rare in classrooms where learners are actively engaged and interested in the work and when they are appreciated for where they come from, whom they are, and what they are able to contribute (Ashworth et al. 2008).

\section{Positive Teacher-Learner Relations}

Positive teacher-learner relations and classroom environments are important factors that will have an influence on how learners experience school. In the same vein, teachers do not only teach knowledge and skills, they also help learners to define whom they are (Charles 2002).

From their daily interactions with teachers, learners learn whether they are important or not, bright or slow, liked or disliked. Teachers transmit these messages through their behaviour, gestures, and words. From the messages learners receive, they decide whether to risk participation in class activities or not. Spaulding (1992) contends that teachers must recognise that involvement may not always come easily and that this requires a trusting, psychologically comfortable classroom environment. The motivation to learn and to behave is based on interest. If teachers manage to stimulate curiosity among learners, they will also discover willingness among learners to learn and to behave. Teaching that satisfies learners' curiosity motivates them far more effectively than forcing them to perform tasks they consider irrelevant and boring. Therefore, the way teachers interact with and teach learners is crucial in preventing misbehaviour.

According to Charles (2002), despite efforts of positive interaction, bad behaviour may still occur and teachers must be prepared for this by using different techniques, ranging from counselling, focusing on understanding, or mutually solving a problem to ignoring inappropriate behaviour while reinforcing appropriate behaviour. 


\section{Research Design and Methodology}

According to Blaikie $(2000,21)$, a research design "is an integrated statement of and justification for the more technical decisions involved in planning a research project [...] This process is analogous to the activities of an architect designing a building." In addition to the explanation, a research design focuses on the end product and all the steps in the process to achieve the anticipated outcome. A research methodology refers to the strategies applied in any form of investigation (De Vos et al. 2002). According to Creswell (2014), descriptive research aims to explain the type of phenomenon surveyed in this study. This study was conducted in six selected secondary schools in the Vhembe district and involved Grade 10 learners. An interview is an effective research instrument to get relevant information from the respondents if it is well prepared (Tuckman 1978).

A qualitative case-study research approach was employed to answer the question of how learner discipline practices can be turned around through epistemic social justice theory to improve the quality of teaching and learning in schools. According to Leedy (2013, 141), "a case study is used to study a particular situation in depth for a specific period". The qualitative research methodology was adopted because it allowed for interaction with participants, which enabled the researcher to construct their social reality. To achieve the aim of this study an interpretive, naturalistic approach was pursued to reach an in-depth understanding of the phenomenon under study. Three principals and three teachers from secondary schools agreed to participate. The qualitative research methodology was chosen because it derives meaning from the research participants' perspective (McMillan and Schumacher 2010). This is supported by Reaves (1992) who posits that qualitative researchers are primarily concerned with the process rather than the outcomes of the products. The qualitative research in this article focuses on how the turnaround of learner discipline in secondary schools will be attained. The researcher chose a qualitative paradigm because it facilitates inductive and descriptive research that commences with data collection and builds on the theoretical framework, which in this study is linked to the turnaround of learner discipline practices through epistemic social justice in schools.

\section{Population}

Okeke and Van Wyk (2015) refer to a population as a group of persons, objects or items from which samples are taken for measurement, for instance a population of dissertations and theses of postgraduate students. This study's population included principals, teachers, parents, and learners of secondary schools in the Vhembe district.

\section{Sampling}

By means of the convenience sampling method, six secondary schools in the Vhembe district were selected. This sampling method was used because the schools are easily accessible in terms of distance. Purposive sampling was used to select three principals, three teachers and three parents - nine respondents. The teachers were selected because 
of their daily learner discipline practices. Learners were selected as participants to gain their perceptions of disciplinary issues from their experience as the major victims. The role of the parents was to provide views on disciplinary issues from an educational and social perspective. The teachers' role is to maintain learner discipline from both an educational and social perspective. The principals, representing the SMT, provided perceptions based on their experience of interpreting and exercising disciplinary measures according to policy. In the context of this study, the SGB is considered as representative of the parents.

Permission to conduct the research pertaining to learner discipline practices was first sought from the Department of Education in Limpopo Province. The researcher selected the schools from the list that was secured at the various ward offices in the region. Phone calls to the principals produced a roster of teachers, learners and parents who would participate in the research. There were informants in each of the three categories: principals, teachers, and parents. Since the SGB represents the parents, the researcher did not deem it necessary to obtain permission from the parents. After permission had been granted, the researcher met separately with the informants (principals, teachers, and parents) and explained the outline and objectives of the research and the role of the informants. A general meeting was set up after school hours for this purpose in each school. It was difficult to accommodate the parents' work schedules, and as a result, few parents attended these meetings. At this gathering, the researcher assured the parents, principals, and teachers of confidentiality, privacy and anonymity during the research process. The rights of the informants were spelled out clearly; that is, they could refuse to answer any questions during interviews, withdraw from the research at any stage, and demand to see any notes or recordings.

The principals, teachers, and parents were reluctant to become involved. However, three principals and three teachers from secondary schools agreed to participate. The informants were diverse with respect to "race", gender, school setting and social and economic contexts. Pseudonyms are used for all informants throughout the project.

\section{Data Analysis}

Qualitative techniques were used to collect the data, which included the interviews with respondents, field notes, and an analysis of documents and education policies of the Department of Education (DoE) and relevant audio materials. The researcher reviewed the data after each interview to extract issues covered during the interview in order to ensure that those issues received preference in the subsequent interview. The actual data analysis took place after all the interviews had been conducted. The data was transcribed, and the analysis was categorised into various stages. In the first stage, data was segmented into categories, and in the second stage related themes were compared to implemented learner discipline practices. 


\section{Findings}

The researcher established themes concerning turnaround learner discipline practices as perceived by principals, teachers, and parents of learners in six secondary schools in the Vhembe district of Limpopo. I also examined the views of principals, teachers, and parents regarding current classroom management practices and the factors that play a role in learner discipline practices.

The findings include, the school was seen as a machine and the classroom as a part of the "machine bureaucracy"; the teacher was seen as a supervisor and the learner as a worker. Common assessments were used as quality-measuring tools employed to rank the learners' performance. Authority was hierarchically structured. Furthermore, the patriarchal and hierarchical social pattern was maintained by a system of command and controls at all the levels of the hierarchy.

A discussion of the results is presented below under the topics that emerged during the data analysis. These are the following: implementation and knowledge explosion, bullying, politics and teachers' unions, multicultural education, and human dignity.

\section{Implementation and Knowledge Explosion}

One finding that emerged from the perceptions of the selected principals, teachers and parents shows that, as part of an exercise to turn around learner discipline and the piloting of standards through a form of training, the Department of Education initiated a teacher-training model intended to spread knowledge and skills (Van der Horst and McDonald 1997). Although the intention was theoretically viable, the programme was simply not workable in an environment that was so unreceptive. The Department of Education procured the services of non-governmental organisations to deliver the nationwide training and evaluate the cascading of training in the entire province. The following are selected comments from the respondents, mostly principals, teachers, and parents:

Participant 1 (Teacher) said:

Classrooms with positive behaviour have a common vision, mission and support the value of citizenship from learners.

Participant 2 (Teacher) declared that:

The management seminars to train social skills to assist learners deal with anger in a constructive and positive manner.

Participant 3 (Teacher) asserted the following: 
The curriculum recognises the bad behaviour is due to loss of control. Trained learners and facilitators guide participants through the management curriculum that offers learners a wide variety of alternative options to express and deal with anger.

Participant 1 (Parent) expressed that:

Learners who have been involved in a fight must attend this programme. Other learners may attend the seminar.

Participant 1 (Principal) echoed the sentiments expressed by Participant 1 and stated that

[t]he outcome of the teacher-parent campaign, parental and school governing meetings is to increase parental involvement for the programme's success and to encourage parental participation.

Participant 2 (Principal) said that what is required is

[a] whole school discipline policy, implemented curricular measures, empowerment of learners through conflict resolution, classroom management and peer counselling. Teacher supervision has increased at a key time.

\section{Bullying}

The interviews indicated that bullying is a violent, physical or psychological form of behaviour that is prevalent in schools and can be reduced, if not eliminated, by actions taken by schools and parents. The respondents indicated that bullying is intolerable behaviour, because it is the cruel oppression of a powerless person by a more powerful person without any justification. The following selected comments from the respondents support this.

Participant 3 (Teacher) related that

[b]ullying is a sign of bad behaviour and affect[s] the ability of other learners to mentally, physically, socially and academically perform.

Participant 1 (Learner) stated that

[1] earners who engage in bullying seem to have a need to feel powerful, in control and to dominate.

Participant 3 (Teacher) said that a

[d]iscipline plan that addresses bullying is a right decision considered.

Participant 2 (Parent) claimed that 
[t]he plan should involve all learners, teachers, principals and parents to make sure that all learners can attend a safe, caring and responsible classroom.

\section{Politics and Educators' Unions}

The analysis brought to light that involvement in politics and teachers' unions is detrimental to discipline and the smooth running of the classroom. Secondary teachers, like other teachers, organise themselves into professional unions and associations for several reasons, namely, to improve the status of the teaching profession, to raise and maintain professional standards, and to look after their interests as employees.

Participant 3 (Parent) contended:

The involvement in politics and teacher unions is detrimental to the smooth running of the classroom and discipline.

As employees, teachers are concerned with their personal needs and economic welfare. The teachers' associations negotiate with education authorities on issues such as the increment of salaries, housing subsidies, medical allowance, working and appointment conditions. The unions constitute the official channel for grievances to be stated to the DoE.

Participant 2 (Teacher), supporting the views of Participant 3, claimed:

The various political organisations are viewed by some of Vhembe secondary teachers as problematic for the effective implementation of classroom management and discipline. Teachers who belong to the same political organisation always club together and support each other on various issues. When staff meetings are to be held, teachers belonging to the same political organisations always caucus in advance on issues to be addressed. Teachers who belong to the minority political organisation are defeated on issues. Those whose political party is well supported receive a reasonable workload at the expense of others.

\section{Multicultural Education}

Based on the researcher's findings, it was evident that multicultural classrooms pose huge challenges to classroom management and discipline. Benson (2008) shows that multicultural education is an approach to teaching and learning that is based upon beliefs, attitudes, knowledge and values, and affirms cultural pluralism within a culturally diverse society and independent world.

Participant 2 (Parent) emphasised the following:

Multicultural education is comprised of the movement towards equity, classroom reform, the process of becoming multicultural and a commitment to combat prejudice and discrimination. 


\section{Human Dignity}

Human dignity (Section 10 of the Constitution [RSA 1996b]), the right of people to be treated with respect and dignity, plays a significant role (Coetzee et al. 2015). Teachers should in all their dealings with learners keep the learners' right to human dignity in mind. Dignity is regarded as the backbone of the South African Constitution. Everyone is entitled to be treated with respect and dignity. In this article, dignity implies respect for the teachers and learners as well as other school communities.

\section{Discussion}

It is evident from the findings that the turnaround of learner discipline in secondary schools in the Vhembe district of Limpopo poses challenges for principals, teachers, and parents. To achieve effective learner discipline, the principals, teachers, learners, and parents must work together. According to Blandford (1998), the learners have human rights that they expect to enjoy, and they also have the right to a learning environment that is conducive to effective learning, safe and non-threatening. Teachers should respect the learner as an individual with human rights such as freedom of expression (Coetzee et al. 2015). Similarly, learners have the right to a learning environment that is free from bullying and intimidation. Parental workshops should be organised by the schools to educate the parents on their roles in enhancing learner discipline in the school. In the same vein, parents should be informed that the home is a socialising agent for children and should be safe and conducive to their well-being and social development. It follows that classroom-based strategies that actively teach and reward positive learner discipline expectations have been shown to be effective at reducing learner discipline problems, and in turn may improve the classroom climate. According to Epstein (2011), there is a shift from the use of exclusionary learner discipline practices to the use of positive, proactive learner discipline and classroom management practices, such as establishing learner discipline expectations.

\section{Opportunities for Further Research}

To successfully implement the modern idea of educational and personal guidance means that educators must have sufficient time to talk to learners about their personal adjustments and needs. Parents must be brought into the picture if the needs of the learners are to be fully met. Modern education, in the core curriculum, also envisages extensive community relationships. The educators must have free time to develop these relationships. At this stage, the school should be planning and effecting a change in the teachers' schedules to provide extra time for them to meet the learners, parents and the community, and have some time to plan and take care of the details of the general problem.

Positive classroom discipline practices thrive on consistency and teamwork. The staff and administrative team should be expected to reinforce the same behaviour for the learners and follow common disciplinary practices. All teachers should work hand in 
hand to the benefit of learners, the school and the classroom. Learners and teachers want to be certain that they are safe, and every precaution and intervention should be considered to make sure that this outcome is accomplished. Rewarding learners for good behaviour and positive contributions to their community is important. Activities should be planned to focus on positive behaviours and appropriate actions of the learners. Every attempt should be made to put the names, pictures, and groups of well-behaving learners on classroom noticeboards and announce their names at assembly.

Evaluation should be an ongoing process and intervention strategies for reducing disruptive classroom behaviour should be assessed continuously for their impact on the overall success of learner discipline practices. One of the suggestions from teacher participants was to develop and establish focus groups that work with at-risk learners and counselling and positive peer mentoring for learners who receive repeated discipline referrals. Data should be collected and used to continuously improve classroom discipline and implement new procedures that could improve the process. An annual evaluation should be conducted on the strengths and needs of discipline practices. The parents suggested that potential barriers come from problems at home that are brought to the classroom environment. They also suggested that the schools should have various programmes to equip the parents and their children with positive knowledge. Parents noted that teachers and representative councils of learners (RCLs) need developmental training skills to equip them to deal with challenging situations. Parents spoke of the need for financial training and relevant seminars and workshops concerning classroom management training and professional development for the teachers. The teachers expressed their opinion that more adults need to be involved during the changing of lessons. A lack of consistent classroom routines was considered a barrier. According to teachers, parents who are passive in participation or unwilling to involve themselves in their children's education are another barrier.

Most participants expressed the idea that teachers should encourage parents to establish and maintain appropriate learner discipline and management practices throughout the academic year. Teachers suggested that it is very important to establish and communicate high expectations for the learners. Opportunities should be created for the learners to experience success in learning activities and good behaviour. They also noted that teachers could regularly monitor classroom activities and give learners constructive feedback to establish positive learner behaviour. Principals acknowledged progress when teachers maintain a brisk instructional pace and make smooth transitions between classroom activities.

\section{Multicultural Education}

Cultures should be viewed on an equal footing, since no culture is superior or inferior to another - there are simply different cultures, each with its own strengths and weaknesses (Ashworth et al. 2008). Multicultural societies are also viewed as an obstacle to the epistemic social justice process because multicultural groups have 
different perceptions of turning around learner discipline. School principals and teachers should be properly trained in cultural aspects. They can in turn produce new quality materials and teacher guides, which will enhance teacher empowerment and curriculum development. Evertson and Weinstein (2006), in support of the idea, stated that a relevant curriculum is one that is culturally sensitive. Educators in multicultural societies, such as South Africa, are increasingly faced with the challenge of managing culturally diverse classes.

\section{Suspension}

Suspending a learner for unacceptable behaviour should aim at turning around learner discipline, maintaining peace and order, and protecting the learner psychologically and physically. In addition, it is also seen as an effective way of dealing with learner discipline. School principals who are using the epistemic social justice rules show that they are resolving learner discipline problems in schools (Shaw 2007). When suspension is used, its effect on the developmental level of the learner and its short- and long-term consequences for the learner should be considered. Furthermore, in-school suspension is recommended more than out-of-school suspension if its duration is clearly spelt out. A plan must be provided for suspended learners so that they can continue to learn. For this purpose, the establishment of in-school suspension centres accompanied by a well-thought-out learning programme should be considered.

\section{Teacher Training Programmes}

Teacher training sessions and in-service training programmes should include relevant modules that are devoted to the behavioural problems of learners and classroom management. The assumption that teachers learn appropriate discipline management skills during their pre-service training is misleading. Experienced and novice teachers get into classroom situations where they are confronted with a lack of suitable strategies to handle behavioural problems.

\section{Conclusion and Recommendations}

As this study has indicated, appropriate learner discipline is vital to attain successful teaching and learning. Without a classroom atmosphere conducive to learning, teachers cannot positively teach, and learners cannot positively learn. Appropriate learner discipline practices involve all stakeholders. Teachers should be at the forefront by being available and accessible. Moreover, teamwork, transparency, accountability, open communication systems and good public relations are necessary. The school management team and teachers are responsible and accountable for carrying out learner discipline practices to ensure success. The chosen learner discipline practices should reflect shared expectations and an obligation to deal with classroom and school problems in a real way. Positive practices will deal with the causes of learners' misconduct. Whatever the design, positive learner discipline practices should inspire a good climate in which the learners take responsibility for their behaviour, treat one 
another with kindness and respect and learn the value of productive work. Parents are the first link in preventing behavioural problems in learners. Parents who are involved in their children's daily classroom activities have a better understanding of what is acceptable in the classroom environment. Most parents are distressed to find that the classrooms they remember with orderly rows and learners paying quiet attention now look disorderly and chaotic. Acts of learner violence, chronic disruptions, bullying and intimidation frequently occur. A good partnership between families and the schools is required to turn the tables. Parents' involvement is the initial stage in cooperative preclassroom education programmes where the learners learn discipline practices firsthand from early childhood teachers. However, parents must continue to be involved as essential partners throughout their children's school years.

School managers and teachers stated that they feel more confident about learner discipline practices evolving when they have access to quality professional development opportunities. These opportunities should emphasise prevention practices. Time for dialogue and administrative support is a key component. Teachers should be given sufficient time to engage in conversations about strategies that work with many opportunities for peer coaching and development courses. All the staff members should be assured that habitually disruptive learners will be suspended and made to attend alternative educational rehabilitation programmes, and the school climate should be free of intimidation. Learner discipline practices thrive on consistency and teamwork. The staff and administrative team should be expected to reinforce the same behaviour for the learners and follow common discipline practices. All educators should work hand in hand to the benefit of the learners, the school, and the classroom.

Evaluation should be an ongoing process, and strategies for reducing classroom disruptions should be assessed continuously for their impact on the overall success of learner discipline practices. One of the suggestions from teacher participants was to establish focus groups that work with at-risk learners, and counselling and positive peer mentoring should be available for learners that receive repeated discipline referrals. Data should be collected and used to continuously improve learner discipline and new procedures that could improve the process should be implemented. An annual evaluation should be conducted on the strengths and needs of discipline practices. Exclusionary learner discipline practices, such as the removal of a learner from the classroom, are not always successful. When a learner is sent to the school principal's office in an effort to reduce his/her disciplinary problems, some learners may regard the use of this exclusionary learner discipline practices as punitive, although other learners may be rewarded by such practices if they are actively encouraged to avoid the classroom.

\section{References}

Amanchukwu, R. N. 2011. "The Role of Parents in the Effective Management of Primary Education in Rivers State”. African Journal of Social Sciences 1 (3): 136-41. 
Anderson, E. S. 2005. "Feminist Epistemology: An Interpretation and a Defense". In Feminist Theory: A Philosophical Anthology, edited by A. E. Cudd and R. O. Andreasen, 188-209. Oxford: Blackwell Publishing.

Ashworth, J., S. Van Bockern, J. Ailts, J. Donnelly, K. Erickson, and J. Woltermann. 2008. "The Restorative Justice Center: An Alternative to School Detention". Reclaiming Children and Youth 17 (3): 22-26.

Benson, M. 2008. "Perspectives of the Teacher". In School Management: The Task and Role of the Teacher, edited by Dirk Badenhorst. Pretoria: Kagiso Publishers.

Blaikie, N. 2000. Designing Social Research: The Logic of Anticipation. Cambridge, MA: Blackwell Publishing.

Blandford, S. 1998. Managing Discipline in Schools. London: Routledge.

Burger, C., D. Strohmeier, N. Spröberd, S. Baumane, and K. Rigby. 2015. "How Teachers Respond to School Bullying: An Examination of Self-Reported Intervention Strategy Use, Moderator Effects, and Concurrent Use of Multiple Strategies". Teaching and Teacher Education 51: 191-202. https://doi.org/10.1016/j.tate.2015.07.004.

Caravita, S. C. S., P. D. Blasio, and C. Salmivalli. 2009. "Unique and Interactive Effects of Empathy and Social Status on Involvement in Bullying”. Social Development 18 (1): 140 63. https://doi.org/10.1111/j.1467-9507.2008.00465.x.

Cassidy, T. 2009. "Bullying and Victimisation in School Children: The Role of Social Identity, Problem-Solving Style, and Family and School Context". Social Psychology of Education 12: 63-76. https://doi.org/10.1007/s11218-008-9066-y.

Charles, C. M. 2002. Building Classroom Discipline. 7th ed. New York, NY: McGraw-Hill.

Coetzee, S. A., E. J. Van Niekerk, J. L. Wydeman, and S. P Mokoena. 2015. An Educator's Guide to Effective Classroom Management. Pretoria: Van Schaik.

Creswell, J. W. 2014. Research Design: Qualitative, Quantitative and Mixed Methods Approaches. 4th ed. Thousand Oaks, CA: Sage Publications.

Dalporto, D. 2013. "Restorative Justice: A Different Approach to Discipline". We Are Teachers. Accessed December 1, 2016. http://www.weareteachers.com/restorative-justicea-different-approach-to-discipline/.

De Vos, A. S., H. Strydom, C. B. Fouché, and C. S. L. Delport. 2002. Research at Grassroots: For the Social Science and Human Service Professions. Pretoria: Van Schaik.

DoE (Department of Education). 2012. School Management Teams: Managing and Leading Schools. Pretoria: CTP Book Printers. 
Elam, S. M., L. C. Rose, and A. M. Gallup. 1993. "The 25th Annual Phil Delta Kappa/ Gallup Poll of the Public's Attitudes toward Public Schools". Phi Delta Kappan 75 (2): 137-54.

Epstein, J. L. 2011. School, Family, and Community Partnerships: Preparing Educators and Improving Schools. 2nd ed. Philadelphia: Westview Press.

Fricker, M. 2007. Epistemic Injustice: Power and the Ethics of Knowing. Oxford: Oxford University Press. https://doi.org/10.1093/acprof:oso/9780198237907.001.0001.

Goldsmid, S., and P. Howie. 2014. "Bullying by Definition: An Examination of Definitional Components of Bullying”. Emotional and Behavioural Difficulties 19 (2): 210-25. https://doi.org/10.1080/13632752.2013.844414.

Gregory, A., R. J. Skiba, and K. Mediratta. 2017. "Eliminating Disparities in School Discipline: A Framework for Intervention”. Review of Research in Education 41 (1): 25378. https://doi.org/10.3102/0091732X17690499.

Higson-Smith, C., and H. Brookes. 2001. Responses to Gender-Based Violence in Schools. Pretoria: HSRC Press.

Leedy, P. D. 2013. Practical Research: Planning and Design. New York, NY: MacMillan.

McMillan, J. H., and S. Schumacher. 2010. Research in Education: Evidence-Based Inquiry. 7th ed. Boston, MA: Pearson Education.

Medina, J. 2012. The Epistemology of Resistance: Gender and Racial Oppression, Epistemic Injustice, and Resistant Imaginations. Oxford: Oxford University Press. https://doi.org/10.1093/acprof:oso/9780199929023.001.0001.

Evertson, C. M., and C. S. Weinstein, eds. 2006. A Handbook of Classroom Management: Research, Practice and Contemporary Issues. Mahwah, NJ: Lawrence Erlbaum.

Morrison, B. 2001. "The School System: Developing Its Capacity in the Regulation of a Civil Society". In Restorative Justice and Civil Society, edited by H. Strang and J. Braithwaite, 195-210. Cambridge: Cambridge University Press.

Mpanza, G. 2015. "Challenges of School Governance: A Case Study of a Secondary School in Gauteng”. PhD diss., University of the Witwatersrand. http://wiredspace.wits.ac.za/handle/10539/18452.

Nieuwenhuis, S., G. Aston-Jones, and J. D. Cohen. 2005. "Decision Making, the P3, and the Locus Coeruleus-Norepinephrine System”. Psychological Bulletin 131 (4): 510-32. https://doi.org/10.1037/0033-2909.131.4.510.

Okeke, C., and M. Van Wyk. 2015. Educational Research: An African Approach. Cape Town: Oxford University Press. 
Petrie, P., J. Boddy, C. Cameron, V. Wigfall, and A. Simon. 2006. Working with Children in Care: European Perspectives. Maidenhead: Open University Press.

Porteus, K., S. Vally, and T. Ruth. 2001. Alternatives to Corporal Punishment. Johannesburg: Heinemann.

Rawls, J. 1999. A Theory of Justice. Revised ed. Cambridge, MA: The Belknap Press of Harvard University Press.

Reaves, C. C. 1992. Quantitative Research for the Behavioural Sciences. New York, NY: John Wiley.

RSA (The Republic of South Africa). 1996a. South African Schools Act, No. 84 of 1996. Government Gazette Vol. 377, No. 17579. Cape Town: Government printers. Accessed May 7, 2020. https://www.gov.za/sites/default/files/gcis_document/201409/act84of1996.pdf.

RSA (The Republic of South Africa). 1996b. Constitution of the Republic of South Africa, No. 108 of 1996. Pretoria: Government printers. Accessed May 8, 2020. https://www.gov.za/sites/default/files/images/a108-96.pdf.

Russell, D., and N. Cranston. 2012. “An Examination of Professional Development Offerings for School Leaders in One Large Education System”. Leading and Managing 18 (1): 1-18.

Shaw, G. 2007. "Restorative Practices in Australian Schools: Changing Relationships, Changing Culture". In "A World of Possibilities: Conflict Resolution Education and Peace Education around the Globe", edited by T. S. Jones, special issue, Conflict Resolution Quarterly 25 (1): 127-35. https://doi.org/10.1002/crq.198.

Smit, M. H. 2009. "A Model for the Improvement of Democratic School Governance in South Africa: An Education Law Perspective". PhD diss., North-West University. https://dspace.nwu.ac.za/bitstream/handle/10394/2906/MHSmit.pdf?sequence=1\&isAllow $\mathrm{ed}=\mathrm{y}$.

Spaulding, C. 1992. Motivation in the Classroom. New York, NY: McGraw-Hill.

Spaull, N. 2013. South Africa's Education Crisis: The Quality of Education in South Africa 1994-2011. Report Commissioned by the Centre for Development and Enterprise (CDE). Johannesburg: CDE. Accessed 19 April 2016. http://www.section27.org.za/wpcontent/uploads/2013/10/Spaull-2013-CDE-report-South-Africas-Education-Crisis.pdf.

Thompson, L. 2015. "Participatory Governance? Citizens and the State in South Africa". International Journal of Education 42 (1): 1-14.

Thornberg, R. 2015. "School Bullying as a Collective Action: Stigma Processes and Identity Struggling”. Children and Society 29 (4): 310-20. https://doi.org/10.1111/chso.12058. 
Tuckman, B. W. 1978. Conducting Educational Research. New York, NY: Harcourt Brace Jovanovich.

Ugboko, F. E., and A. A. Adediwura. 2012. "A Study of Principal Supervisory Strategies and Secondary School Discipline”. Journal of Educational and Social Research 2 (1): 41-49.

Van der Horst, H., and R. McDonald. 1997. Outcomes-Based Education: A Teacher's Manual. Pretoria: Kagiso Publishers.

Woolman, S., and B. Fleisch. 2009. The Constitution in the Classroom: Law and Education in South Africa (1994-2008). Pretoria: Pretoria University Law Press (PULP).

Xaba, M., and D. Ngubane. 2010. "Financial Accountability at Schools: Challenges and Implications". Journal of Education 50: 139-59. Accessed May 14, 2020.

http://joe.ukzn.ac.za/Libraries/No_50_2010/Financial_accountability_at_schools_challeng es_and_implications.sflb.ashx. 